\title{
BRAND MANAGEMENT PRO-SOCIAL ACTIVITIES AS AN EFFECTIVE ELEMENT OF IMAGE STRATEGY
}

\author{
ZARZĄDZANIE MARKĄ. DZIAŁANIA PROSPOŁECZNE \\ JAKO SKUTECZNY ELEMENT STRATEGII WIZERUNKOWEJ
}

https://doi.org/10.34739/zn.2021.56.01

\author{
Marek Nocoń ${ }^{1}$, Magdalena Różycka² \\ ${ }^{1}$ Poland, University College of Tourism and Ecology, Faculty of Social Sciences, \\ mareknocon@wste.edu.pl, ORCID 0000-0003-4133-7286 \\ 2 Poland, University College of Tourism and Ecology, Faculty of Tourism and Leisure, \\ rozycka.m@interia.pl, ORCID 0000-0002-4818-3294
}

\begin{abstract}
The aim of this article is to research the effectiveness of pro-social actions in the building of a brand image and if it really might be an effective determinant of marketing actions - which has an influence on consumer choices: chosen aspects of pro-social actions used in the strategies of NIVEA and Rossmann drugstores are explored here. In addition, analyzes of pro-social actions during pandemic was carried out. It is proved that companies which took a part in relief efforts during the crisis were appreciated by consumers; which helped when it came to creating brand value. The most important question seems to be not "Whether to invest in CSR?" but "How to invest?" This issue is sure to become the subject of numerous research projects and analyzes in the future.
\end{abstract}

Keywords: management, marketing strategy, Corporate Social Responsibility, social marketing, NIVEA, Rossmann

Abstrakt: Celem artykułu jest zbadanie, na ile działania prospołeczne są skuteczne przy budowaniu wizerunku marki i czy w istocie mogą być efektywną determinantą działań marketingowych, mających wpływ na konsumenckie wybory. Dla potrzeb publikacji zbadano wybrane aspekty działań prospołecznych wykorzystywanych w strategiach marketingowych firmy NIVEA oraz Drogerii Rossmann. Ponadto przeprowadzono analizę ich działań prospołecznych w czasie pandemii. Dowiedziono, iż firmy, które włączyły się w działania pomocowe w kryzysie, są doceniane przez konsumentów, co sprzyja kreowaniu wartości marek. Najważniejszym wydaje się więc współcześnie nie pytanie: „Czy inwestować w CSR?”, lecz: „Jak inwestować?”. Tematyka ta w przyszłości stanie się przedmiotem licznych badań i analiz.

Słowa kluczowe: zarządzanie, strategia marketingowa, Społeczna Odpowiedzialność Biznesu, marketing społeczny, NIVEA, Rossmann

\section{Introduction}

The evolution of marketing business management has led to an increased importance of branding. However, building a brand requires systematic and well-planned activities. Companies therefore reach for various types of marketing tools in order to differentiate their brand in a competitive market. This is identical to the concept formulated by $\mathrm{J}$. Trout Stand out or die (Trout, 2002).

One of the increasingly used techniques is social marketing. It is in line with the principle of "enlightened egoism" where organizations strive to generate such beneficial results for society that will also lead to generating positive results for themselves (Kostera, 2010, 46) As Kostera emphasizes "we used to help to help, now we help to make money" (Kostera, 2010, 46).

The aim of this article is to examine to what extent pro-social activities are effective in building brand image and whether, in fact, they can be an effective determinant of marketing activities influencing consumer choices. Moreover, whether such activities fulfil their function in times of pandemic - when, in fact, social, business and marketing communication (which is a function of business) has moved to a virtual space. 
Research shows that the number of internet users has seen strong growth in 2020. 4.57 billion people worldwide now use the internet, representing nearly 60 percent of the world's total population. The global total grew by 346 million over 2020, an increase of more than 8 percent year-on-year. On average, this means that about 11 new users went online for the first time every second from July 2019 to July 2020 (Majchrzyk, 2020). The year of 2020 changed a lot in the areas of economy, communication, entertainment, and the psychology of social interaction. The coronavirus has created a global community - and this, after the universal experience of the threat, will certainly change outlooks on many issues (Borowski et al., 2020).

For the purposes of this publication, selected aspects of pro-social activities used in the marketing strategies of NIVEA and Rossmann Drugstores were examined in the context of, among others, brand recognition. It seems that in times of crisis, when social expectations are growing, especially towards global brands, it is important to build positive relationships with potential consumers. Companies that have joined in the relief efforts during the crisis are appreciated by consumers, which has contributed to creating value for their brands and, in the long run, to their economic efficiency. This will be proved in the following publication.

\section{Literature review. Brand management in the context of pro-social activities}

According to Kotler, "Perhaps the greatest art of marketing is the ability to create, maintain, protect and improve a brand" (Kotler, 1994, 410). This means that the proper goal of marketing planning is to increase value for loyal customers; and brand image management is the main tool for this process (Kotler, 1994, 412).

The process of brand image management is considered to be a difficult and complicated process, taking into account its psychological, sociological, marketing and communication dimensions, as well as the multiplicity of contemporary communication tools influencing its creation. Therefore, in this process attention should be paid to all necessary elements which should constitute a coherent identity. However, "this requires integrated marketing communication (IMC) management, which is a complex process requiring a systematic and interdisciplinary approach" (Różycka, 2015, 73).

We are currently witnessing a marketing model that is primarily focused on the customer, where it is important to satisfy the needs of consumers not necessarily engaged with the product. In this case, we can speak of postmodern consumer behaviour, in which consumers expect the satisfaction of post materialistic needs (Ingelhart, 2006; Gambetti and Graffigna, 2010).

We are currently witnessing the development of Marketing 3.0, or the era of value orientation. The potential customer is looking for something to make the world a better place. They are looking for companies that include in their mission and the values they represent objectives that meet the desires of social, economic and environmental justice. It is true that a product or service is supposed to meet functional and emotional needs, but customers also expect spiritual fulfilment (Kotler, 2010, 18). The goal of companies that operate according to version 3.0 is to provide solutions to social problems. Through their actions, these companies are able to interact with their customers at a higher level and differentiate themselves in the market through their values. In times of rapid change, values provide a strong and unique position for a company (Kotler, 2010, 19).

P. Doyle formulated the concept of value marketing. He does not deny the previous achievements of marketing (Doyle, 2005, 12) but argues for the necessity of taking a new look at its purpose. He argues that all marketing ventures should be evaluated in the context of creating value for investors. Traditionally formulated marketing objectives, such as increasing consumer awareness and loyalty, market shares and others, in the author's opinion, are no longer clearly translated into financial results. The competitive advantage is now gained by those companies that are best able to build partnerships with all entities in the environment, contributing to the creation and development of customer relationships (Gordon, 2001, 24).

The concept of corporate social responsibility, which has its origins in the late 18th and early 19 th centuries, when large industrial enterprises were established and developed, and economic transformations took place, is connected with value marketing (Fijałkowska, 2014, 112). Nowadays, it is the subject of interest and practice of many enterprises, due to globalization, which increases competitiveness, the growing influence of enterprises, the transformation of passive clients into conscious consumers, and the growth of investors' expectations, and an increase in the importance of the organization's material resources (Filipp, 2008, 457).

CSR may be taken into account by companies in their internal environment, i.e. social relations within the organization. In the pursuit of employee development, reliable communication, overcoming gender, racial, sexual and religious discrimination, as well as in the external environment, e.g. by 
striving to counteract pollution of the natural environment, sponsoring social and cultural events or co-financing charity actions aimed at improving the welfare of discriminated groups (Głuszek, 2008, 78).

Companies do not limit themselves to supporting social initiatives, but also establish their own associations, organizations and foundations, which are in line with the idea of corporate social responsibility. However, it is interesting to know whether the involvement in this type of activities stems only from a desire to improve people's lives, or whether it is one of the effective marketing and promotional tools through which the company tries to promote and create a positive brand image, which is the sum of views, attitudes, feelings, impressions that a person or group has in relation to a given company (Głuszek, 2008, 78). CSR is often mistakenly identified with the public relations strategy, reducing it solely to communication and building relations with the environment. It is worth stressing that social responsibility is the subject of communication, to achieve the intended effects, and not a type of communication strategy. CSR communication results from the wish to arouse the recipient's interest in the enterprise and brand, with the additional effect of increasing credibility and sending a message about the good condition of the company, managed in a transparent way, responsibly building its image and caring for good relations with its environment (Głuszek, 2008, 201).

The literature formulates the view that "social marketing is the application of commercial marketing techniques to the analysis, planning, implementation and evaluation of programs that influence the intentional behaviour of selected groups of customers, with the aim of improving the well-being of individuals and the condition of society" (Jacennik, 2000, 25). Potential customers pay attention to how the manufacturer responds to social needs (Czubała, 2013, 29). Taking "American Express" as an example, we can talk about socially engaged marketing in business. The company applied this form of marketing communication on a national level by organizing a fund-raising event for the Statue of Liberty in 1983. The campaign ran for three months and was designed to encourage consumers to shop with their American Express card. The company donated 1 cent for each purchase and $\$ 1$ for the setting up of a new card account. As a result, $\$ 1.7$ million was donated to the restoration of the statue. American Express helped to popularize the term "cause-related marketing". It was, in fact, the beginning of defining this issue in economics (Śmigielska, 2009).

P.R. Varadarajani and A. Menon were the first who defined this phenomenon. According to the authors, "cause-related marketing is the process of preparing and implementing marketing activities, characterized by the company's declaration of a specific monetary contribution to a socially important cause each time customers engage in a revenue-generating exchange, which will allow the realization of both the goals of the organization and individuals" (Czubała, 2013, 30). Socially engaged marketing differs from charity in that corporate money is not a direct donation to a notfor-profit institution and is therefore not tax deductible. The potential gain for businesses is increased sales and increased buyer and employee loyalty (Czubała, 2013). Therefore, this marketing should aim for a win - win situation where all parties involved are winners, the nonprofit institution, the enterprise and also the consumer (Czubała, 2013).

The conclusion of the above considerations may be the statement that pro-social activity influences the way the brand is perceived by recipients (Jupowicz-Ginalska, 2010). This is in line with the already mentioned principle of "enlightened egoism", according to which organizations strive to generate such beneficial results for society that will at the same time lead to generating positive results for themselves (Kostera and Śliwa, 2010, 46) Examples of activities in line with the idea of "enlightened egoism" include, for example, initiatives in the field of social marketing by media organizations, e.g. the Polsat Foundation, the TVN Foundation, the Radio Zet Foundation.

\section{Cooperative philanthropy. Testing the effectiveness of pro-social activities on the example of two cosmetics companies: NIVEA and Rossmann}

The NIVEA brand reaches its consumers with the slogan: One box, 100 years of memories (Official NIVEA brand website). However, NIVEA is not only the cosmetics. It has been involved in CSR actions for 15 years. It has been supporting the development of families and local communities for many years. During the last 15 years of active social engagement in Poland, the NIVEA brand has organized such campaigns as i.e., "Safe with NIVEA and WOPR". These programs enjoyed great interest not only from local communities but also the media (Zaangażowanie społeczne). What is important is the fact that the company uses the potential of social media to promote its marketing and pro-social campaigns.

NIVEA Beiersdorf is a company whose main communicated values are: care, simplicity, courage and trust. The company declares responsible behaviour towards colleagues, 
customers, brands, society, and the environment, and emphasizes its social commitment. The declared responsibility of NIVEA Beiersdorf focuses on three areas: products, planet and people (Official Beiersdorf corporation website).

Rossmann is company that is also involved in social campaigns. In 1991, Dirk Rossmann founded a charitable foundation in Germany to support development programs for birth control and AIDS policies in the so-called Third World countries (Superbrands Poland project website, information brochure on the Rossmann brand).

In Poland, it supports charity, pro-social and cultural initiatives - both nationwide (e.g. TVN "Nie jesteś sam" Foundation, distribution of the "Gentlemen" calendar, the proceeds from which are allocated to the purchase of shoes for children from the poorest families - the "Stop barefoot" campaign) and local (mainly Łódź). It also initiated the social "Rossmann Hygiene Academy" campaign (Superbrands Poland project website, information brochure on the Rossmann brand). It uses the potential of social media to communicate with potential consumers. New technologies shape the purchasing habits of consumers all over the world. The use of social media influences the sale of products and services. An example is how Internet users reacted to discounts in Rossmann. The Institute of Media Monitoring monitored the promotional frenzy across the Rossmann chain. IMM monitoring revealed that Rossmann's promotional campaign caused a visible increase in publications about the brand in social media (Polowanie w Rossmannie. Jak internauci zareagowali na przeceny). The avalanche of interest is mainly the effect of sharing information about the promotion. Almost 65 thousand mentions of the brand appeared in the media. On the Android operating system the Rossmann application is already the 10th most popular mobile application in Poland. All points collected by Rossmann customers within the Club are donated to selected foundations and for environmental protection (Kralka 2018).

\section{Results of the research}

The research tool used in this publication is a questionnaire. 107 respondents took part in the study. The research group consisted of 83 women $(77.6 \%)$ and 24 men. The age structure of the respondents was as follows: 18-26 (59.8\%), 27-34 $(24,3 \%), 35-40(5,6 \%)$ and over $40(10,3 \%)$ years old. The aim of the survey was to verify the respondents' knowledge on companies' pro-social activities. To confirm or deny the hypothesis that they may be an important determinant of consumer choices. Prosocial activities of NIVEA and Rossmann were analysed. The study made it possible to analyse the effectiveness of these actions. As well as to examine brand recognition of the companies subject to the study. From the research perspective, it seemed important to examine brand recognition of NIVEA and Rossmann. The results are presented in Figure 1.

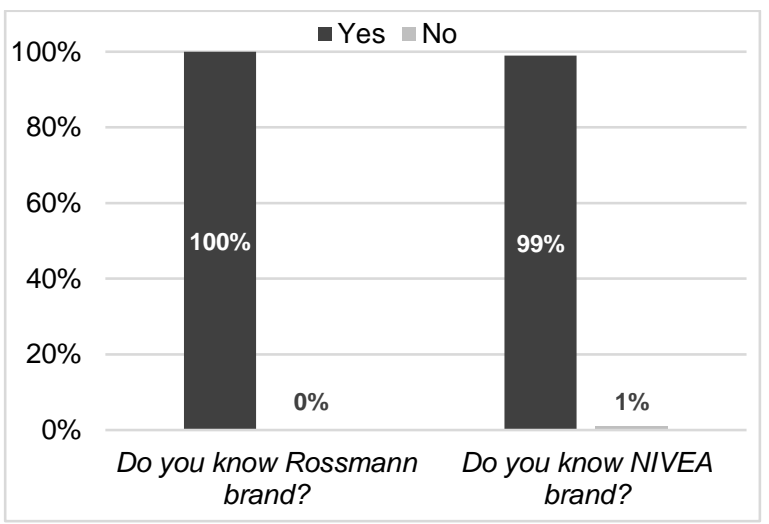

Figure 1. Recognition of Rossmann and NIVEA brands Source: own research.

The survey analysis confirmed a very high brand recognition. Rossmann totalled $100 \%$, whereas the NIVEA brand was at a level of $99 \%$.

The respondents were also questioned about their use of the company's products. It concerned products signed with the NIVEA brand. The survey showed that $74.8 \%$ of the respondents use NIVEA cosmetics, whereas $25.2 \%$ do not use them (Table 1).

Table 1. Behaviour and attitudes of consumers in relation to the NIVEA and Rossmann brands

\begin{tabular}{|c|c|c|}
\hline Question & Yes & No \\
\hline Do you use Nivea cosmetics? & $74,8 \%$ & $25,2 \%$ \\
\hline $\begin{array}{l}\text { Do you do shopping in the } \\
\text { Rossmann drugstore? }\end{array}$ & $93,5 \%$ & $6,5 \%$ \\
\hline $\begin{array}{l}\text { Do you know Nivea's social } \\
\text { campaign " } 100 \text { playgrounds for } \\
100 \text { years of NIVEA"? }\end{array}$ & $74,8 \%$ & $25,2 \%$ \\
\hline $\begin{array}{l}\text { Do you use Rossmann } \\
\text { drugstore application? }\end{array}$ & $75,7 \%$ & $24,3 \%$ \\
\hline
\end{tabular}

Source: own research.

The analysis of the results shows that a significant proportion of the respondents use NIVEA products. This confirms that the brand has high recognition and a rich offer that encourages potential customers to purchase its products.

Since the previous research confirmed the high recognition of the Rossmann brand (Fig. 1), the frequency of purchases in the chain of drugstores of this brand was also analysed.The respondents 
confirmed that as many as $93.5 \%$ of them do the shopping at Rossmann. Only $6.5 \%$ of respondents declared that they do not shop at the selected drugstore. It can be assumed that Rossmann is popular as a result of the wide range of products that it offers, which encourages potential customers to make purchases.

The survey also focused on an awareness of NIVEA's social campaign "100 playgrounds for 100 years of NIVEA". Despite the high awareness of the NIVEA brand, there were some people who did not know this campaign. Out of 107 respondents, the mentioned campaign was known to 80 people $(74,8 \%)$. The remaining respondents $(25,2 \%)$ had no knowledge of the campaign. It can therefore be concluded that these people are not interested in NIVEA's social activities and that these activities do not influence their consumer choices.

The respondents were also asked to evaluate the effectiveness of the mentioned campaign on a scale of 1 (low) -5 (high) (Fig. 2).

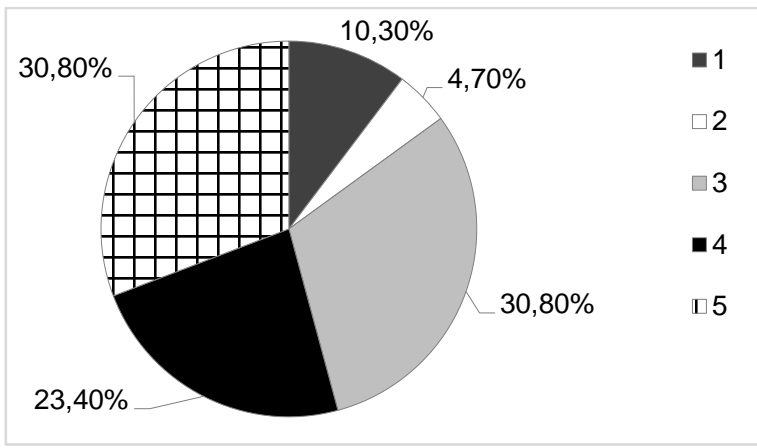

Figure 2. Rating of effectiveness of the NIVEA social campaign

Source: own research analysis.

Respondents who showed familiarity with NIVEA's pro-social action "100 playgrounds for 100 years of NIVEA" rated its effectiveness well, over $50 \%$ rated it at the level 4 and 5 . It can therefore be assumed that these actions have an impact on their consumer choices and on NIVEA brand itself.

The knowledge of the Rossmann application was also analysed (Table 1). As many as 81 people $(75,7 \%)$ use the Rossmann application, which indicates its popularity.

More than half of the respondents are aware of the fact that the points collected in the application are transferred to a social organization of their choice.

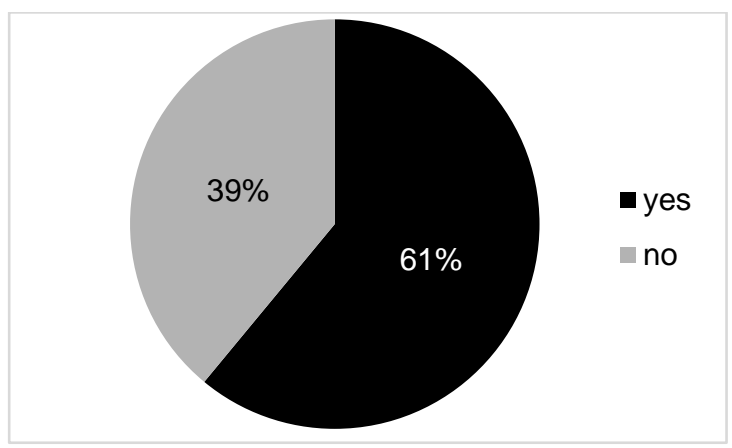

Figure 3. Knowledge of purpose of collecting points within the Rossmann application

Source: own research analysis.

It can be assumed that this awareness results from an efficiently conducted information campaign. The effectiveness of the above-mentioned campaign was also evaluated, as presented in Figure 4.

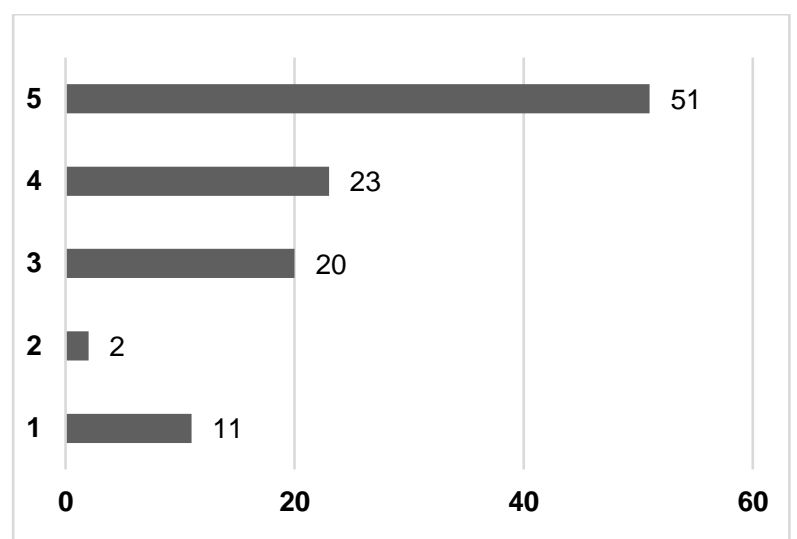

Figure 4. Rating of effectiveness of the Rossmann social campaign

Source: own research analysis.

Almost half of the respondents rated the effectiveness of the campaign well. On a scale of 1 (low) to 5 (high), $47,7 \%$ of respondents rated is on level 5 and $21,5 \%$ on level $4.18,7 \%$ of respondents rated it on the medium level and the rest gave the low rate. It has to be pointed that in general effectiveness of the Rossmann campaign was ranked as more effective than the one by NIVEA. Sum of the answers 4 and 5 in t case of the NIVEA campaign is on the level of $54,2 \%$ and in the case of Rossmann it is $69,2 \%$.

The analysed activities of NIVEA and Rossmann fit into the model of the so-called Marketing 3.0. In this approach, the consumer is defined primarily as a human being who is an individual with his own values, aspirations, and needs. In this case, the spiritual aspect of the offer is taken into account during marketing planning. The concept of Marketing 3.0 oscillates around building the brand identity and community around higher values. The key point here is the focus on 
achieving positive values from the point of view of both the company's shareholders and society, including customers and intermediaries.

In terms of technology, Marketing 3.0 uses the so-called new wave technology and sees the consumer as a member of a specific promotion. In terms of strategy implementation, Trexy marketing (a term created by combining the words "trendy" and "sexy") together with its Brand 3.0 and Web 3.0 tools are useful. Trexy marketing involves tying consumers to a specific brand through the use of innovative and out-of-the-box solutions such as viral marketing, word-of-mouth marketing, and guerrilla marketing (Niedzielska, 2011).

It can be concluded that Web 3.0 is a combination of social elements (Web 2.0) with sales and direct communication. In essence, Brand 3.0 is "a desirable model of cooperation between both entities (company and customer), focused on a two-way flow of information" (Jenkins, 2007, 25). In other words, this instrument makes it possible to build a brand according to consumer preferences, thus creating a long-term relationship with customers. Brand 3.0 is also called social marketing, because it allows the audience to influence the actions of the company and its e-image (Jenkins, 2007, 13).

In the context of the above considerations, it should be pointed out that the actions of Rossmann drugstore resulted in the title of 'Superbrands 2021' in the category of drugstores and the most popular drugstore in the ranking of users of the Listonic application. The Superbrands title is awarded to the strongest and best perceived brands on the Polish market. The survey is conducted every two years and is the largest study of brand strength in Poland. The ARC Rynek i Opinia Research Institute surveyed 10 thousand consumers on over 2 thousand brands (Jankowski 2021). Rossmann also turned out to be the most popular drugstore in the "Report on retail chains in Poland", whose author is Listonic, a shopping planning application. Rossmann was followed by, as in 2019: Hebe, Super-Pharm and Natura. Rossmann stood out from other chains by introducing safe forms of shopping: at least one self-service checkout in each drugstore and by launching a new function in the Rossmann PL application - Rossmann GO. It enables customers to scan products with their phone and pay online with a payment card connected to the application.

It seems interesting to see how, in times of a pandemic, the companies identified in the publication use marketing to communicate their value to potential consumers. Thus, NIVEA set up an international financial support programme worth $€ 50$ million in 2020 . Its aim was to support local communities in the fight against the COVID-
19 pandemic (Walka z COVID-19 trwa 50 milionów Euro od NIVEA). Among the actions implemented and planned were:

- Donation of 1,000,000 litres of disinfectants.

- Provide at least 5,000,000 NIVEA skin and hand care products to medical personnel worldwide.

- Direct financial support to non-governmental organizations, both international organizations and local partners, which are currently facing major challenges.

\section{Conclusion}

The subject of this publication was pro-social activities of companies serving the brand and building advantage on the competitive market. It can be assumed that the 'concepts of social marketing focus mainly on the perception of a brand by the society. More and more companies use this tool of communication with the market to increase not only profits, but also their market position.

The positive aspects of the activity of companies analysed in this article confirm the effectiveness of pro-social activities. These are by all means the right activities, worth continuing, even if the idea of helping is not entirely altruistic, because it leads to creating a positive image of companies, which in a perspective, translates into consumer decisions. Taking up this topic by the author seemed important, because of the growing interest in corporate social responsibility, as well as the insufficient level of knowledge in this area. CSR is a positive phenomenon, as it contributes to mitigating certain social problems, creating a positive image, and as a result ensures a good economic position for the company. In the author's subjective opinion, criticism of this type of activity seems to be unjustified. Moreover, it can be recognized that business in pandemic times is subject to constant evolution. Referring to the theory proposed by Śmigielska (2015), it can be observed that in the case of the companies covered by the research presented in the article, a win-win situation can indeed be observed. According to the results of the research, it is clear that consumers, especially in the case of Rossmann, are strongly involved in the social action conducted by the company within the mobile application, which is undoubtedly an in-plus situation from the point of view of the public benefit organisations to which the funds collected within the action go, and from the point of view of the drugstore chain itself. A high number of downloads of the application and, above all, the percentage of people shopping online directly indicates an increase in profits achieved by the company. 
Therefore, this situation confirms the claim of Koster and Śliwa (2010) that at the moment one helps in order to earn money. The latest survey of the Responsible Business Forum shows that almost 80 percent of companies introduced into their activities various types of pro-social actions addressed to employees or customers during the pandemic. These efforts are positively assessed by 7 out of 10 respondents (Konsumenci wybrali przyjazne sieci wśród drogerii).

It seems that especially in times of crisis, paradoxically, there is a great social need for "order, a sense of security and faith in fixed and unchangeable values. We want the world around us to be predictable, sensible and friendly, so there is a great need for ethics, or - using economic language - a demand for it" (Dróżdż, 2008,146). Observing the CSR activities undertaken by companies around the world during the COVID-19 pandemic, one can see how the approach to corporate social responsibility is changing. Companies are increasingly focusing on directly supporting their immediate community, concentrating on initiatives to mitigate the effects of the crisis (Piskulski 2015). It can be assumed that similar efforts will be made in the case of future crises. The most important question nowadays seems to be not "Should we invest in CSR?" but "How to invest" (Konsumenci wybrali przyjazne sieci wśród drogerii). Certainly, this topic is set to be the subject of numerous studies and analyses in the future.

\section{References}

Borowski, G., Brzezińska, O., Dworak, J., Dzwonek, K., Gromada, A., Jagiełło, K., Kępa, K., Kowalczyk, M., Kusiak, J., Kuśmierz, A., Lewandowska, Z., Maruszewski, M., Nadaždin, D., Nowakowski, M., Olszańska, T., Rudzińska-Bluszcz, Z., Rzeplińska, R., Soluch, P., Stafiej-Bartosik, A., Szala, M., Tarkowski, A., Talewicz-Kwiatkowska, J., Wardziak, T., Wilczyńska, A., Ziobrowski, Z., Ziomecka, Z., Żaba, N. (2020). Jak COVID-19 zmieni Polskę. Prognoza liderów polskich środowisk branżowych $i$ społecznych [How COVID-19 will change Poland. Forecast by leaders of Polish industrial and social environments]. Retrieved from: https://publicystyka.ngo.pl/jak-covid-19zmieni-polske-prognoza-liderow-polskichsrodowisk-branzowych-i-spolecznych.

Czubała, A. (2013). Koncepcja i formy marketingu społecznego przedsiębiorstw [The concept and forms of corporate social marketing]. Zeszyty Naukowe małopolskiej Wyższej Szkoły Ekonomicznej w Tarnowie 22 (1), 25-34.

Doyle, P. (2005). Marketing wartości [Marketing values]. Warszawa: Felberg.
Drożdż, M. (2008). Konwergencja mediów tendencje, modele i konsekwencje [The convergence of media - trends, models and consequences]. Studia Medioznawcze 3 (34), 84-103.

Fijałkowska, J. (2014). Społeczna „nie odpowiedzialność" biznesu [The social irresponsibility of business]. In: Ł. Sułkowski, M. Zawadzki, Krytyczny nurt zarządzania [Critical aspects of management]. Warszawa: Difin.

Filipp, E. (2008) Społeczna odpowiedzialność organizacji [Social corporate responsibility]. In: M. Kostera (Eds.), Nowe kierunki $w$ zarządzaniu [New management directions], (pp. 95-113). Warszawa: Wydawnictwa Akademickie i Profesjonalne.

Gambetti, R.C., Graffigna, G. (2010). The concept of engagement. A systematic analysis of the ongoing marketing debate. International Journal of Market Research, 52 (6), 801-826.

Głuszek, E. (2008). CSR jako narzędzie budowania wizerunku firmy [CSR as a tool for building brand recognition]. Prace naukowe Uniwersytetu Ekonomicznego (5), 193-203.

Gordon, I.H. (2001). Relacje z klientem, Marketing partnerski [Customer Relations - a marketing Partnership]. Warszawa: PWE.

Ingelhart, R., Pojawienie się wartości postmaterialistycznych [The appearance of post-material values]. In: P. Sztompka, M. Kucia, (Eds.), Socjologia. Lektury, (pp. 334348). Kraków: Wyd. Znak.

Jankowski, J. (2021). Silna marka, z którą Polacy najchętniej planują zakupy [A strong brand with which Poles most willingly plan their shopping]. Retrieved from: https://www.rossmann.pl/firma/ $\mathrm{pl-pl/biuro-prasowe/informacja/silna-marka-z-}$ ktora-polacy-najchetniej-planujazakupy,649515.

Jacennik, B. (2000). Perspektywy marketingu społecznego w Polsce [Prospects for social marketing in Poland]. Retrieved from: http://www.psychologia.edu.pl/czytelnia/50artykuly/629-perspektywy-marketinguspolecznego-w-polsce.html.

Jenkins, H. (2007). Kultura konwergencji. Zderzenie starych $i$ nowych mediów [The culture of convergence. Old and new media collide]. Warszawa: Wyd. Akademickie i Profesjonalne.

Jupowicz-Ginalska, A. (2010) Marketing Medialny [Media Marketing] Warszawa: Wyd. Difin S.A.

Kostera M., Śliwa M. (2010) Zarządzanie w XXI wieku [Management in the 21st Century]. Warszawa: Wyd. Akademickie i Profesjonalne

Kotler, Ph. (1999). Marketing. Warszawa: Felberg SJA.

Kotler, Ph. (2001). Marketing po rewolucji [Marketing after the Revolution]. Warszawa: Businessman Magazine. 
Kotler, Ph. (2010). Marketing 3.0. Warszawa: MT Biznes.

Kralka, J. (2018). Aplikacja Rossmann bije rekordy popularności po promocji $2+2$ gratis do pielęgnacji włosów [The Rossmann app breaks records of popularity after the promotion of $2+$ 2 free for hair care]. Retrieved from:

https://bezprawnik.pl/aplikacja-rossmann/.

Majchrzyk, Ł. (2020). Mobile i digital w 2Q 2020 jak pandemia wpłynęła na cyfrowy krajobraz [Mobile and digital in Q2 2020 - how the pandemic affected the digital landscape]. Retrieved from:

https://mobirank.pl/2020/07/21/ mobile-idigital-w-2q-2020-jak-pandemia-wplynela-nacyfrowy-krajobraz/.

Niedzielska, A. (2011). Marketing 3.0 w przedsiębiorstwie jutra [Marketing 3.0 in the businesses of tomorrow]. Zeszyty Naukowe Uniwersytetu Szczecińskiego, Problemy usług (74), 387-399.

Nowakowska, A. (2021). W 2021 roku Pomagamy jak umiemy kobietom [In 2021, we help women as best we can]. Retrieved from: https://www.rossmann.pl/firma/pl-pl/biuroprasowe/informacja/w-2021-roku-pomagamyjak-umiemy-kobietom, 632403 .

Piskulski, G. (2015). Społeczna odpowiedzialność biznesu w polskich realiach [Social Corporate Responsibibility in the Polish Reality]. Warszawa: Fundacja CentrumCSR.PL.

Różycka, M. (2015). Marketing medialny a dialogowość Internetu [Media marketing and internet dialogue]. Zarządzanie mediami 3(1), 59-75.

Śmigielska, G. (2009). Marketing społecznie zaangażowany - mariaż marketingu i społecznej odpowiedzialności [Socially engaged marketing - a marriage of marketing and social responsibility]. Zeszyty Naukowe Uniwersytetu Szczecińskiego. Problemy Zarządzania, Finansów i Marketingu (26), 459469.

Trout, J. (2002). Wyróżnij się lub zgiń [Stand out or fail]. Warszawa: IFC Press.

\section{Internet references}

Konsumenci wybrali przyjazne sieci wśród drogerii. Retrieved from:

https://www.wiadomoscikosmetyczne.pl/artyku ly/konsumenci-wybrali-przyjazne-sieci-wsroddrogerii-,66116.

Official NIVEA brand website: https://www.nivea.pl

Official Beiersdorf corporation website: https://www.beiersdorf.com/.

Polowanie w Rossmannie. Jak internauci zareagowali na przeceny. Retrieved from: https://www.imm.com. pl/imm-polowanie-wrossmannie-jak-internauci-zareagowali-naprzeceny/.

Superbrands Poland project website, information brochure on the NIVEA brand: http://superbrands.pl/wp-content/ uploads/2014/03/2008_Nivea.pdf

Superbrands Poland project website, information brochure on the Rossmann brand: http://superbrands.pl/wp-content/uploads/ 2014/04/Rossmann.pdf

Walka z COVID-19 trwa 50 milionów Euro od NIVEA. Retrieved from: https://biznestuba.pl/ featured/walka-z-covid-19-trwa-50-milionoweuro-od-nivea/.

Zaangażowanie społeczne. Retrieved from: https://www.niveapol-ska.pl/zrownowazonyrozwoj/local/pl/ zaangazowanie-spoleczne/csr. 